\title{
ADVERSE REACTIONS TO FIRST-LINE ANTI-TUBERCULOSIS DRUGS AS A RISK FACTOR OF PULMONARY TUBERCULOSIS TREATMENT DEFAULT IN JAKARTA, INDONESIA
}

\author{
STEFANUS IMANUEL SETIAWAN ${ }^{*}$, PURWANTYASTUTI ASCOBAT ${ }^{2}$
}

${ }^{1}$ Faculty of Medicine Universitas Indonesia, Jakarta, ${ }^{2}$ Department of Pharmacology and Therapeutic, Faculty of Medicine Universitas Indonesia, Jakarta

Email: imanuelstefanus@gmail.com

Received: 12 Dec 2018, Revised and Accepted: 10 Mar 2019

\section{ABSTRACT}

Objective: Tuberculosis (TB) is one of the leading fatal infectious diseases and remains a major health problem worldwide. Moreover, adverse effects of TB treatment can escalate treatment default. This study aimed to evaluate the correlation between adverse reactions to anti-TB drugs and treatment default.

Methods: We performed a cross-sectional study using medical record data of a total 172 adult patients with pulmonary TB who were treated with firstline anti-TB drugs at Dr. Cipto Mangunkusumo National General Hospital in Jakarta, Indonesia during 2014 and who experienced adverse reactions.

Results: Of the total, 127 patients (73.8\%) had minor adverse reactions and 45 patients (26.2\%) experienced major adverse reactions. Predominant adverse reactions included gastrointestinal disorders (34\%) and drug-induced hepatitis (60\%). There was a significant correlation between adverse reactions to anti-TB drugs and treatment default cases (odds ratio (OR), 9.33; 95\% confidence interval (CI), 4.20-20.72; p<0.001). The results of multivariate analysis showed that TB treatment outcome is affected by adverse drug reactions $(0 \mathrm{R}, 10.91 ; 95 \% \mathrm{CI}, 4.62-25.75$; $\mathrm{p}<0.001)$, drug use in treating concomitant diseases (OR, 3.03; 95\% CI, 1.30-7.05; $\mathrm{p}=0.010)$, and type of anti-TB drug used (OR, 2.41; 95\% CI, 0.99-5.83; $\mathrm{p}=0.045)$.

Conclusion: Based on these results, we showed that adverse reactions to anti-TB drugs can affect TB treatment outcome and can serve as a risk factor to treatment default.

Keywords: Adverse reaction, Anti-tuberculosis drug, Treatment default, Pulmonary tuberculosis

(C) 2019 The Authors. Published by Innovare Academic Sciences Pvt Ltd. This is an open access article under the CC BY license (http://creativecommons. org/licenses/by/4. 0/) DOI: http://dx.doi.org/10.22159/ijap.2019.v11s6.33551

\section{INTRODUCTION}

Tuberculosis (TB) is one of the leading fatal infectious diseases and remains a major health problem worldwide. In 2013, the World Health Organization (WHO) estimated that there were more than 9 million incident TB cases, $64 \%$ of which were new sputum smearpositive cases, and that about 3 million TB cases remain undiagnosed with 1.5 million TB-related deaths worldwide. In 2015, Indonesia become the country with the second highest incidence of TB globally, with a total 0.7-1.4 million cases per year [1]. About, $75 \%$ of TB cases occur in economically productive age groups (15$50 \mathrm{y}$ ), leading to an average loss of working time of 3-4 mo and causing annual income losses of up to $30 \%$. Based on Ministry of Health data, Indonesia's success rate for TB treatment reached $85 \%$ percent among new smear-positive TB cases in 2013, slightly below the national target of $88 \%$ [2]. The factors contributing to TB treatment outcome include patient compliance, patient knowledge and behavior related to TB, and health services. Moreover, patient adverse reactions to TB treatment might escalate treatment default [3]. Based on these facts, additional evidence regarding the influence of adverse reactions to anti-TB drugs may reveal an important determinant in the prevention of treatment default. Hence, further investigation is needed regarding whether adverse reactions to antiTB drugs indeed represent an independent etiologic factor that may contribute to the outcome of TB treatment. The objective of this study was to determine whether there was a correlation of TB treatment default cases with drug side effects and other aspects of TB treatment.

\section{MATERIALS AND METHODS}

\section{Study design, setting, and participants}

We performed a cross-sectional study using secondary data of adult patients with pulmonary TB who had experienced adverse anti-TB drug reactions. All data were collected from medical records of Dr. Cipto Mangunkusumo National General Hospital during 2014. In this study, we included the data of a total 172 patients, based on the following inclusion criteria: adult patient with pulmonary TB who received first-line anti-TB drug treatment and experienced adverse reactions. Adverse reactions were classified into major (hypersensitivity, drug-induced hepatitis, and hearing loss or equilibrium disorders) and minor (red-colored urine, gastrointestinal tract disorders, visual impairment, paresthesia, skin disorders, headache, muscle and joint pain, and flu-like syndrome) adverse effects, based on Indonesian guidelines for TB diagnosis and management by the Ministry of Health Indonesia (2013) [4].

\section{Variable definitions}

Adverse reactions to first-line anti-TB drugs were defined as unexpected effects after receiving anti-TB drugs (rifampicin, isoniazid, pyrazinamide, ethambutol, and streptomycin). In this study, adverse reactions were classified into major and minor adverse effects, with signs and symptoms as described above.

Outcomes of TB treatment in this study were divided into two categories: treatment default and completed treatment. Treatment default is defined as interruption of treatment for more than 2 consecutive months. Completed treatment is defined as treatment completion for the determined duration of treatment $(6$ mo for firstline treatment).

Other potential variables that could affect treatment outcome were also included in this study and extracted for analysis, as follows: socioeconomic status, comorbid diseases, and drug use for comorbid diseases. The definition of socioeconomic status is a measure of class standing influenced by social class, educational level, income, and occupation. In this study, we also categorized patient data according to age group (15-54 y, $>54 \mathrm{y}$ ), sex (female/male), and occupation (unemployed, government worker, self-employed, private sector employee, farmer, and other).

\section{Data analysis}

Quantitative data were analyzed using IBM SPSS 20 software (IBM Corp., Armonk, NY, USA). The chi-square test was used for bivariate 
analysis and variables with $\mathrm{p}$ value $<0.20$ were included in multivariate analysis using logistic regression.

\section{Ethics}

Ethical approval to conduct the study was obtained from the Faculty of Medicine, Universitas Indonesia Research and Ethics Committee. Permission to conduct this study was also given by the Center for Clinical Epidemiology and Evidence-Based Medicine, Dr. Cipto Mangunkusumo National General Hospital.

\section{RESULTS}

\section{Participant characteristics}

From a total 172 patients included in this study, 127 patients (73.8\%) experienced minor adverse reactions to anti-TB drugs, and
45 patients $(26.2 \%)$ had major adverse reactions (table 1 ). The predominant major adverse reactions were drug-induced hepatitis (60\%), hypersensitivity (24\%), and hearing loss or equilibrium disorders (16\%) (fig. 1). Minor adverse reactions included gastrointestinal tract disorders (34\%), paresthesia (16\%), redcolored urine $(13 \%)$, skin disorders $(9 \%)$, muscle and joint pain (9\%), visual impairment (6\%), headache (5\%), and others (8\%) (fig. 2). In this study, 70 patients $(40.7 \%)$ had comorbidities requiring the use of antiretrovirals, antifungals, antibiotics, antipyretics, immunosuppressive agents, corticosteroids, pump proton inhibitors, $\mathrm{H} 2$ receptor antagonists, sucralfates, analgesics, antidiabetic drugs, antihypertensive drugs, and others. Pump proton inhibitors, H2 receptor antagonists, and sucralfates were the most commonly used drugs for comorbidities (25\%), followed by antidiabetic drugs (14\%), antihypertensive drugs (13\%), and antibiotics (13\%).

Table 1: Patient characteristic based on research variables

\begin{tabular}{|c|c|c|c|c|}
\hline S. No. & Variable & & Frequency & Percentage (\%) \\
\hline \multirow[t]{2}{*}{1} & Adverse reactions & Minor adverse effects & 127 & 73.8 \\
\hline & & Major adverse effects & 45 & 26.2 \\
\hline \multirow[t]{2}{*}{2} & Treatment default & No default & 132 & 76.7 \\
\hline & & Default & 40 & 23.3 \\
\hline \multirow[t]{2}{*}{3} & Age, $y$ & $15-54$ & 134 & 77.9 \\
\hline & & $>54$ & 38 & 22.1 \\
\hline \multirow[t]{2}{*}{4} & Sex & Female & 67 & 39 \\
\hline & & Male & 105 & 61 \\
\hline \multirow[t]{5}{*}{5} & Occupation & Unemployed & 72 & 41.9 \\
\hline & & Civil servant & 8 & 4.7 \\
\hline & & Self-employed & 34 & 19.8 \\
\hline & & Private sector worker & 15 & 8.7 \\
\hline & & Other & 43 & 25 \\
\hline \multirow[t]{2}{*}{6} & Anti-tuberculosis drugs & Fixed-dose combination & 118 & 68.6 \\
\hline & & Single-drug formulation & 54 & 31.4 \\
\hline \multirow[t]{2}{*}{7} & Comorbid disease & No & 94 & 54.7 \\
\hline & & Yes & 78 & 45.3 \\
\hline \multirow[t]{2}{*}{8} & Drug use for comorbid disease & No & 102 & 59.3 \\
\hline & & Yes & 70 & 40.7 \\
\hline
\end{tabular}

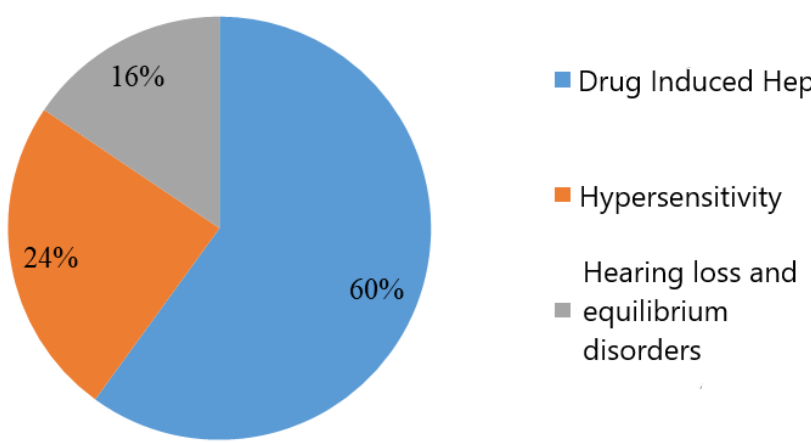

Fig. 1: Distribution of major adverse effects of anti-tuberculosis drugs

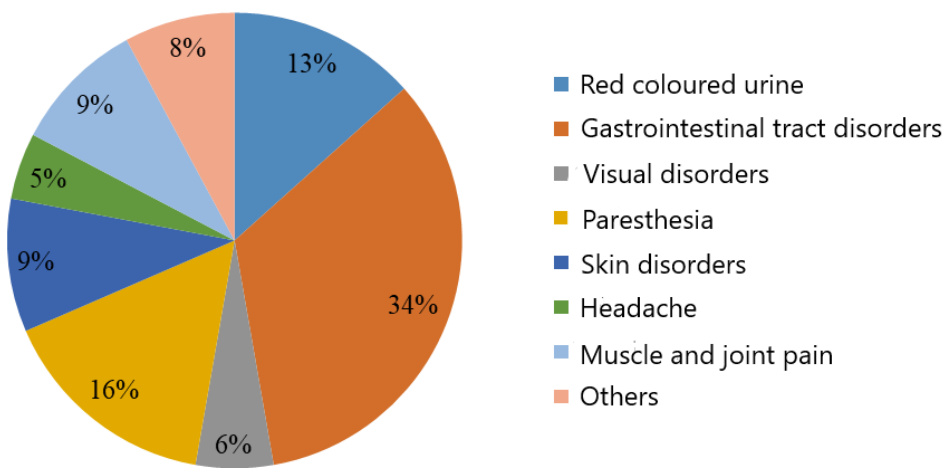

Fig. 2: Distribution of minor adverse effects of anti-tuberculosis drugs 
Table 2: Association between adverse reactions to anti-tuberculosis drugs and treatment default cases

\begin{tabular}{lllll}
\hline Variable & & No default (\%) & Default (\%) & OR (95\% CI) \\
\hline Adverse reactions & Minor adverse effects & $112(88.2)$ & $15(11.8)$ & $9.333(4.204-20.721)$ \\
& Major adverse effects & $20(44.4)$ & $25(55.6)$ & \\
\hline
\end{tabular}

OR, odds ratio; $\mathrm{CI}$, confidence interval

Table 3: Results of multivariate analysis for relationship of research variables with tuberculosis treatment default

\begin{tabular}{lllll}
\hline Variable & Constant & Standard error & OR & 95\% CI \\
\hline Adverse reaction & 2.390 & 0.438 & 10.912 & $4.623-25.754$ \\
Anti-tuberculosis drugs & 0.878 & 0.452 & 2.405 & $0.993-5.829$ \\
Drug used for comorbid diseases & 1.109 & 0.431 & 3.030 & $1.302-7.051$ \\
Constant & -2.881 & 0.439 & 0.001 & 0.045 \\
\hline
\end{tabular}

OR, odds ratio; $\mathrm{CI}$, confidence interval

\section{Adverse reactions to first-line anti-TB drugs as a risk factor of pulmonary TB treatment default}

We conducted bivariate analysis using the chi-square test. We found that several variables had an association with hypertension $(\mathrm{p}<0.05)$, namely, adverse reactions, formulation of anti-TB drugs, comorbid diseases, and drug use for comorbidities. Table 2 shows that major adverse reactions were associated with higher risk of treatment default (OR 9.33, 95\% CI 4.204-20.721). In this study, multivariate analysis was performed using a logistic regression model including the following variables: adverse reactions, socioeconomic status, formulation of anti-TB drugs, comorbid diseases, and drug use for comorbidities. In the final model, those variables related to with treatment default were adverse reactions, formulation of anti-TB drugs, and drug use for comorbidities (table 3 ). The final model variables associated with higher risk of treatment default were adverse reactions (OR, 10.91; 95\% CI, 4.6225.75; $\mathrm{p}<0.001$ ), drug use to treat concomitant diseases (OR, 3.03; $95 \% \mathrm{CI}, 1.30-7.05 ; \mathrm{p}=0.01$ ), and type of anti-TB drug used (OR, 2.41; $95 \% \mathrm{CI}, 0.99-5.83 ; \mathrm{p}=0.045)$.

\section{DISCUSSION}

Demographically, we found that adverse reactions to anti-TB drugs were predominantly minor side effects $(73.8 \%)$. This finding was in accordance with studies conducted by Nazir et al. (2015) and Lu et al. $(2013)[5,6]$. The former authors showed that among a total 306 patients in Lahore, Pakistan, only 31 patients $(10.13 \%)$ experienced major adverse events (drug-induce hepatitis, shock, and hypersensitivity); the remaining 275 patients (89.87\%) experienced minor adverse reactions, primarily muscle and joint pain [5]. Lu et al. conducted a study in China including 766 patients who experienced adverse reactions and found that 374 patients (48.83\%) had major side effects, such as hepatic dysfunction and allergic reaction [6]. In our study, the predominant major adverse reaction was hepatotoxicity. Hepatotoxicity is affected by external and internal patient aspects. Hepatotoxicity occurs with excess accumulation of active metabolites of anti-TB drugs, causing failure of phase II metabolic detoxication, which is commonly regulated by transcription factors such as pregnane $\mathrm{X}$ receptor in the liver. Excessive metabolites could induce the production of reactive oxygen species (ROS), which cause further lipid peroxidation and cell death $[7,8]$. The body has defensive mechanisms that are mediated by nuclear factor erythroid 2-related factor which has a cytoprotective profile [9]. Ramappa et al. (2013) explained that when this defensive aspect can protect against the harmful effects of oxidative stress caused by excessive metabolites or ROS, minimal side effects of anti-TB drugs occur. The main minor adverse reactions to these drugs involve gastrointestinal tract disorders, such as nausea [10, 11]. Kenward et al. (2015) showed that anti-TB drugs can cause nausea when active metabolite forms circulate, acting as emetogenic agents and stimulating vagal release of 5hydroxytryptamine [12].

The results of our final model showed that those variables related to treatment default were adverse reactions, formulation of anti-TB drugs, and drug usage for comorbidities. We found that major adverse reactions increased the risk of treatment default, in accordance with the findings of Rian (2010) and Muture et al. (2011) $[13,14]$. The latter authors showed that anti-TB drug adverse reactions were the third leading factor in treatment default after lack of patient knowledge regarding TB treatment (16.7\%) and long travel distance for patient treatment (12.5\%). In addition, Muture et $a l$. found that the incidence of adverse reactions was associated with patient inconvenience during therapy, which caused the patient to become noncompliant [13]. The formulation of anti-TB drugs is another factor contributing to the outcome of anti-TB therapy. In this study, we divided the formulation into fixed-dose combination and anti-TB drugs given in separate-dose form and found that the separate-dose form increased the risk for treatment default. In accordance with Gallardo et al. (2016), the use of fixed-dose combination has several advantages over the separate-drug form. The advantages of fixed-dose combination drugs are easier administration, convenient dose schedule and better compliance, and simplification of complex treatment regimens [15]. We also found that the use of other drugs for comorbidities have a role in TB treatment outcomes. Gastrointestinal medications (pump proton inhibitors, H2 receptor antagonists, and sucralfates) were commonly used for comorbidities (25\%). Omeprazole can interact with streptomycin and can disturb magnesium metabolism (hypomagnesemia) as well as parathyroid hormone secretion, which can contribute to hypocalcemia. Anti-diabetic drugs (such as metformin) can interact with isoniazid and lower glycemic control, causing hyperglycemia and glucose intolerance. Anti-hypertensive agents such as amlodipine can interact with rifampicin, which lowers the bioavailability, plasma concentration, and pharmacological effect of both drugs by induction of CYP450 3A4. The interaction between anti-TB drugs and medications taken for comorbidities also increases the risk of adverse effects and affects patient compliance $[3,4,16]$.

\section{CONCLUSION}

Based on our study results, we showed that adverse reactions to anti-TB drugs can affect treatment outcome and can serve as a risk factor of treatment default. We observed correlations of adverse reactions, anti-TB drug formulation, and drug use for comorbidities with treatment default in this study. We can conclude that problematic aspects of managing adverse drug reactions together with the management of comorbidities can lead to TB treatment default issues in patient populations worldwide. Public health authorities should focus on problems related to compliance among patients with $\mathrm{TB}$, such as by developing programs to promote compliance and prevent default, within the context of traditional cultural values.

\section{ACKNOWLEDGMENT}

The authors wish to thank Dr. Cipto Mangunkusumo National General Hospital who kindly allowed us to access and analyze their patient data and helped us in so many ways. This article was presented at The $3^{\text {rd }}$ International Conference and Exhibition on Indonesian Medical Education and Research Institute (ICE on IMERI 
2018), Faculty of Medicine, Universitas Indonesia, Jakarta, Indonesia. We thank the $3^{\text {rd }}$ ICE on IMERI Committee who had supported the peer review and manuscript preparation before submitting to the journal.

\section{AUTHORS CONTRIBUTIONS}

All the author have contributed equally

\section{CONFLICTS OF INTERESTS}

The authors declare that there are no conflicts of interest regarding the publication of this paper.

\section{REFERENCES}

1. World Health Organization. Global tuberculosis report; 2015. Available from: http://www.who.int/tb/publications/global_report/en/ [Last accessed 13 Oct 2016]

2. Rofiq A, Karyana M, Azhar K, Syarif AK, Indah RM. Penyakit menular. In: Badan Litbangkes. Riset kesehatan dasar. Kemenkes RI; 2013. p. 69-71.

3. Isbaniyah F, Thabrani Z, Soepandi PZ, Burhan E, Soedarsono, Reviono $\mathrm{R}$, et al. Tuberkulosis: pedoman diagnosis dan penatalaksanaan di Indonesia. Perhimpunan Dokter Paru Indonesia; 2011. p. 24-47.

4. Mustikawati DE, Surya A, Basri C, Kamso S, Manaf A, Pranoto A, et al. Pedoman nasional pengendalian tuberkulosis. Jakarta: Direktorat Jendral Pengendalian Penyakit dan Penyehatan Lingkungan Kemenkes RI; Bab 3, Tatalaksana pasien tuberculosis; 2013. p. 32-7.

5. Nazir A, Imam SF, Shabbir I, Saleem S. Adverse drug reaction of first line anti-tuberculosis drugs used in DOTS implemented setting in Lahore. Pakistan J Med Res 2015;54:101-4.

6. Lu X, Tang S, Xia Y, Wang X, Yuan Y, Hu D, et al. Adverse reactions due to directly observed treatment strategy therapy in Chinese tuberculosis patients: a prospective study. PLoS One 2013;8:e65037.
7. Chantaphakul H, Cheungpasitporn W, Ruxrungtham K, Klaesongkram J. Adverse reaction to anti-tuberculosis drugs. J Allergy Clin Immunol 2010;125:AB154.

8. Xia YY, Hu DY, Liu FY, Wang XM, Yuan YL, Tu DH, et al. Design of the anti-tuberculosis drugs induced adverse reactions in China national tuberculosis prevention and control scheme study (ADACS). BMC Public Health 2010;10:1-9.

9. Delgado KC, Montag AR, Bravo SG, Segovia EV, Montoya AS, Garbin AN. Factors associated with anti-tuberculosis medication adverse effects: a case-control study in Lima, Peru. PLoS One 2011;6:e27610.

10. Ramappa V, Aithal GP. Hepatotoxicity related to antituberculosis drugs: mechanisms and management. J Clin Exp Hepatol 2013;3:37-49.

11. Shang P, Xia Y, Liu F, Wang X, Yuan Y, Hu D, et al. Incidence, clinical features and impact on anti-tuberculosis treatment of anti-tuberculosis drug induced liver injury (ATLI) in China. PLoS One 2011;6:e21836.

12. Kenward H, Pelligand L, Bataille KS, Elliot J. Nausea: current knowledge of mechanisms, measurement and clinical impact. Veterinary J 2015;203:36-43.

13. Rian S. Pengaruh efek samping obat anti tuberkulosis terhadap kejadian default di rumah sakit islam pondok kopi jakarta timur januari 2008-Mei 2010 [Thesis]. Fakultas Kesehatan Masyarakat Universitas Indonesia; 2010. p. 7-31.

14. Muture BN, Keraka MN, Kimuu PK, Kabiru EW, Ombeka VO, Oguya F. Factors associated with default from treatment among tuberculosis patients in Nairobi province, Kenya: a case control study. BMC Public Health 2011;11:696.

15. Gallardo CR, Comas DR, Rodriguez AV, Figuls MR, Parker LA, Cayla J, et al. Fixed-dose combinations of drugs versus singledrug formulations for treating pulmonary tuberculosis. Cochrane Database Systematic Rev 2016;17:CD009913.

16. Pan X, Wang L, Grundemann D, Sweet DH. Interaction of ethambutol with human organic cation transporters of the SLC22 family indicates potential for drug interactions during antituberculosis therapy. Antimicrob Agents Chemother 2013;57:5053-9. 